Research Article

\title{
Species Composition, Relative Abundance, and Habitat Association of Avifauna in Zegie Peninsula Forest Patches and Associated Wetlands, Bahir Dar, Ethiopia
}

\author{
Misganaw Mola $\mathbb{D}^{1},{ }^{1}$ Dessalegn Ejigu, ${ }^{2}$ and Yibelu Yitayih ${ }^{1}$ \\ ${ }^{1}$ Mizan Tepi University, College of Natural and Computational Science, Department of Biology, P.O. Box 121, Tepi, Ethiopia \\ ${ }^{2}$ Bahir Dar University, Science College Department of Biology, P.O. Box 79, Bahir Dar, Ethiopia \\ Correspondence should be addressed to Misganaw Mola; misganawmola@gmail.com
}

Received 20 March 2021; Revised 5 May 2021; Accepted 30 June 2021; Published 10 July 2021

Academic Editor: Irene Pellegrino

Copyright (c) 2021 Misganaw Mola et al. This is an open access article distributed under the Creative Commons Attribution License, which permits unrestricted use, distribution, and reproduction in any medium, provided the original work is properly cited.

\begin{abstract}
Introduction. Ethiopia is one of the most avifauna rich countries in Africa. Avifaunal surveys are required to inform conservation decisions and enhance land management for biodiversity. Avifaunal surveys from Ethiopia are lacking. This study examines species composition, relative abundance, and habitat association of avian fauna in Zegie Peninsula forest patches and associated wetlands from surveys carried out from August 2018 to March 2019, covering both the wet and dry seasons. Data Collection. Forest, shrub, lakeshore, and wetland habitats were identified as ecologically relevant habitats in the study area for data collection. Data were collected using point count and line transect methods, for 24 days in total for both seasons in the morning and afternoon. Results. A total of 96 species of birds were identified during the whole study period. Out of the total, 40 species were observed during the wet season, 13 during dry and 43 species in both seasons. There was significant variation of species distribution among habitats. During the wet season, the highest species diversity was recorded in the wetland habitat followed by forest habitat. During the dry season, avian diversity was the highest in the lakeshore followed by wetlands. The highest evenness was observed in the shrubland during both the wet and dry seasons. During the wet season, the highest species similarity was recorded between wetland and lakeshore habitats, and during the dry season, the highest species similarity was recorded between forest and shrub habitats. Based on encounter rate data, 64 (66.66\%) of the avian species were uncommon. Conclusions. Compared to previous studies conducted in the study area, species diversity was lower. This might be due to various anthropogenic activities such as deforestation of trees for timber and cutting trees for firewood. Therefore, awareness creation should be given to the local community to reduce habitat destruction due to various human-induced factors.
\end{abstract}

\section{Introduction}

Ethiopia has diverse sets of ecosystems ranging from humid forests and extensive wetlands to deserts, supporting a wide variety of life forms $[1,2]$. Its topography varies from vast plains to high mountains having an altitudinal range of $110 \mathrm{~m}$ below sea level (Kobar sink) in the Afar depression to the highest peak at Ras Dejen with an altitude of $4620 \mathrm{~m}$ a.s.l. [3]. Wide altitudinal variation and the extensive areas under Afro-alpine habitat, compared to the rest of Africa, have contributed to the diversity of flora and fauna of Ethiopia [4]. The country is rich in its faunal diversity, and as a result, over 320 species of mammals, over 860 species of birds, 200 species of reptiles, 63 species of amphibians, and 145 species of fish are known [5]. In terms of the avian fauna, Ethiopia is one of the most diverse countries in Africa [6]. Forests, wetlands, and riverine systems are sites for wintering or passaging migrant birds in Ethiopia [1, 7]. To promote the conservation of these birds and their habitats, 73 Important Bird Areas (IBAs) have been identified in Ethiopia, 30 of these sites ( $41 \%$ of total IBAs) comprise wetlands, while the rest are representatives of other ecosystems [8]. Lake Tana and the surrounding area (including Zegie Peninsula) qualify as an IBA because they possess globally threatened 
species such as Wattled Crane (Bugeranus carunculatus), Lesser Flamingo (Phoeniconaias minor), Rouget's Rail (Rougetius rougetti), Pallid Harrier (Circus macrourus), and Greater Spotted Eagle (Aquila clanga) [9]. Over 300 species of bird have been observed and recorded in the Lake Tana Basin, which has been defined as an international bird site by BirdLife International (BLI) [10].

Birds are not restricted to wetlands. They also occupy other habitats like forests, forest edges, grasslands, shrubs, and lakeshores [11]. Forests are important habitats for migrating birds in the major flyways [12]. As primary consumers, birds get nutrients from nectar, fruits, seeds, and vegetative tissues such as roots, shoots, and leaves [13]. The distribution and abundance of many bird species are determined by the composition of the vegetation that forms a major element of their habitats [9]. African forests are home to a particularly wide variety of species [14]. These especially include birds that are associated with vegetation, and the existence of trees is vital to their life cycle [15].

Ecological studies on birds are important to determine the biodiversity in the area and to understand the habitat requirements of the species and population dynamics [16]. In Ethiopia, a limited amount of research has been carried out on avian diversity, distribution, and abundance in different ecosystems, particularly in National Parks and protected areas [17]. The present study focusses on avian species composition, relative abundance, and habitat association in Zegie Peninsula forest patches and associated wetlands.

\section{Methods}

2.1. Description of the Study Area. Zegie is the largest peninsula along Lake Tana and is mostly covered with dense forest. The lake and its adjacent area are registered as UNESCO's Biosphere Reserve site for its rich biodiversity. It extends beyond the southwestern shore of the lake. It is located at coordinates of $11^{\circ} 40^{\prime}$ to $11^{\circ} 43^{\prime} \mathrm{N}$ latitude and $37^{\circ} 19^{\prime}$ to $37^{\circ} 21^{\prime}$ E longitude, $600 \mathrm{~km}$ northwest of Addis Ababa, at an altitude ranging from $1770 \mathrm{~m}$ a.s.l. along the banks of the lake to $1975 \mathrm{~m}$ a.s.l. at its summit called Ararat. Zegie is part of Bahir Dar city administration and is $32 \mathrm{~km}$ from Bahir Dar city in a northwest direction. It can be accessed from and to Bahir Dar by both land and water. Zegie Peninsula includes a town called Zegie (Afaf) and two rural Kebeles, Ura and Yiganda, with an area of 1347 ha [18]. The total size of the study area is 1827 hectares, and an additional 480 ha of land from Wonjita Kebele is included in the wetland habitats. The size of habitats in the study area is $500,460,387$, and 480 hectares for forest, shrub, lakeshore, and wetlands, respectively (Figure 1).

\subsection{Preliminary Survey. The preliminary survey was carried} out in August 2018 to collect information about vegetation types, human settlement, land use, and the topography of the study area. Additional information about the area was gathered from the local people such as previous forest coverage. Global Positioning System (GPS) readings were used to record the locations and to identify the altitudinal ranges of the study habitats.

2.3. Sampling Design. Based on the preliminary survey, the habitats of the study area were identified and categorized into four different habitats depending on the vegetation composition. These are forest, shrubland, lakeshore, and wetland habitats. The forest is a large area dominated by trees and representative of typical dense vegetation. Locally, this site is designated as a conservation area. This site has a closed, dense canopy. The shrubland is located at the boundaries of Ararat Mountain and covered by small to medium-sized woody plants and dwarf trees. This habitat is clearly different from dense forests by its vegetation type and size. This area is dominated by Vernonia schimperi, Capparis tomentosa, Acacia oerfota, and Carissa edulis. The lakeshore represents a transitional area between undisturbed (dense) forest and Lake Tana. The vegetation of this habitat predominantly comprises species of Typha and papyrus [9]. The wetlands are lowland plains and are regularly inundated with water. The area is located toward the western side of Zegie Peninsula at the border of Wonjita Kebele. This area is the transition between a land-based and water-based ecosystem. Sampling units representing each habitat type were selected based on a stratified random sampling method. The technique involved dividing the study area into blocks by choosing the location of each habitat with random numbers [19]. Random blocks were selected for forest, shrubland, lakeshore, and wetland habitats [20]. We applied a grid to each habitat consisting of $0.5 \times 1 \mathrm{~km}$ cells. Then, we randomly selected blocks from the grid resulting in 5 blocks in the forest, shrubland, and wetland and 4 blocks in the lakeshore (Table 1).

In each block, there were point counting stations. The point count stations in a sample block were 150-200 m apart to avoid under- or overestimation during the counting process. The point count method was used to count birds in forest, shrub, and lakeshore habitats [21]. In wetland habitats, we carried out line transects instead of point counts because the habitat is uniform and has less vegetation coverage. Therefore, birds are easily visible. In this habitat, a total of 20 transects were laid down. These transects were separated from each other by 150-200 $\mathrm{m}$ depending on the vegetation cover and accessibility of the area. Census of birds was carried out on foot within a radius of $25 \mathrm{~m}$ at both sides of the transect line following the methods of Aynalem and Bekele [8]. The sequence in which the transects and stations were visited was systematically alternating between sampling periods to partially compensate for the effects of hourly variation in bird activity [22]. Every effort was taken to avoid mistakes during the census period.

2.4. Data Collection. Based on the information gathered during the preliminary survey, fieldwork was carried out from August to October 2018 to collect the wet season data. Dry season data collection was carried out from January to March 2019. Data were collected over six months, i.e., three months during the wet season and three months during the 

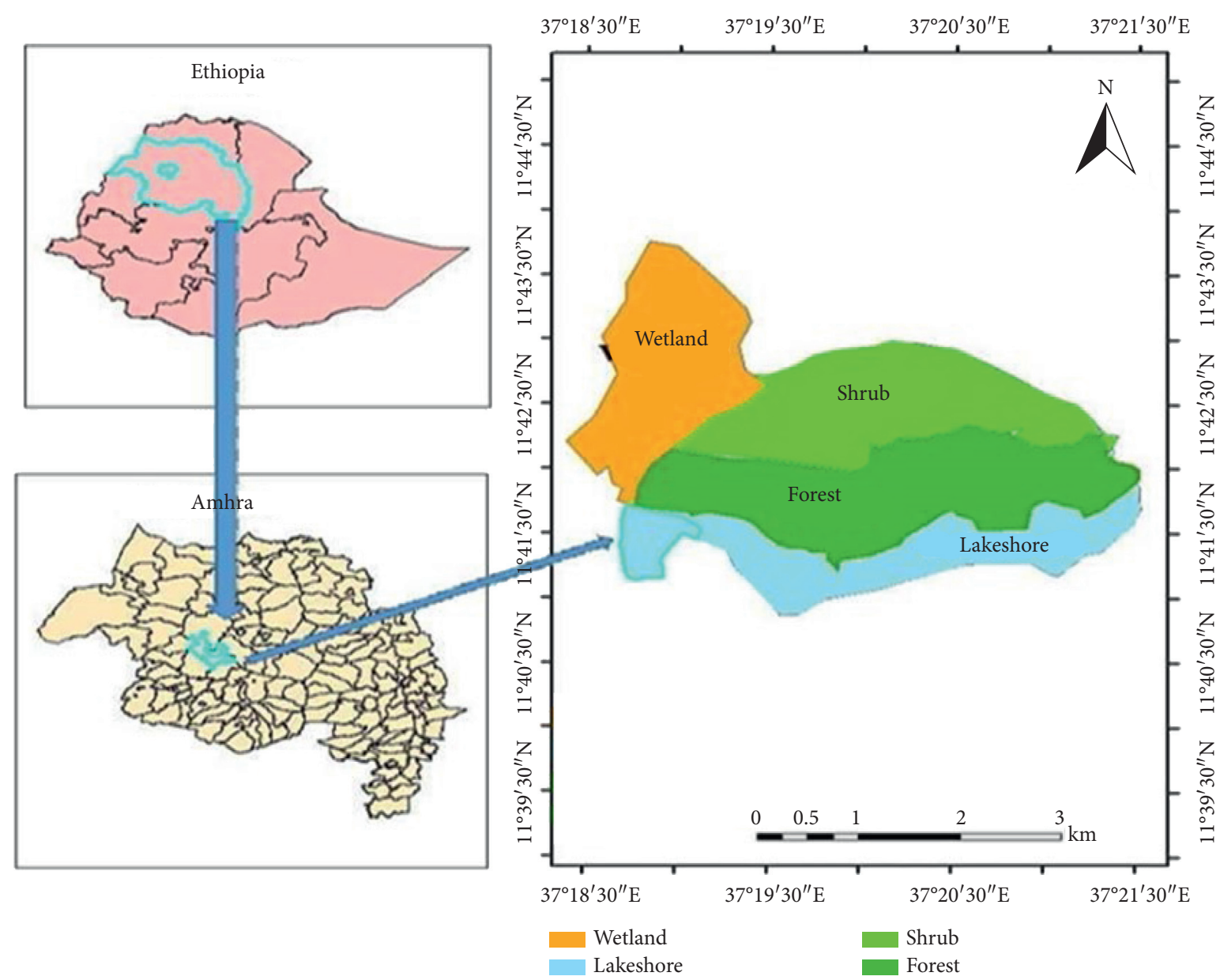

FIgURE 1: Location map of the study area.

TABLE 1: stations for the point count and transect count methods.

\begin{tabular}{lccccc}
\hline Habitat type & Total area $\left(\mathrm{km}^{2}\right)$ & Total blocks $(0.5 \times 1 \mathrm{~km})$ & $\begin{array}{c}\text { Sample blocks } \\
(0.5 \times 1 \mathrm{~km})\end{array}$ & $\begin{array}{c}\text { Number of point stations } \\
\text { Number of line transects }\end{array}$ \\
\hline Forest & $5(500 \mathrm{ha})$ & 10 & 5 & 13 & - \\
Shrubland & $4.6(460 \mathrm{ha})$ & 9 & 5 & 12 & - \\
Lakeshore & $3.87(387 \mathrm{ha})$ & 8 & 4 & - & 20 \\
Wetland & $4.8(480 \mathrm{ha})$ & 10 & 5 & 35 & 20 \\
Total & $18.27(1827 \mathrm{ha})$ & 37 & 19 & & - \\
\hline
\end{tabular}

dry season, for a total of 24 days, i.e., four days per month in both seasons. Data were collected from 6:30 a.m. to 10:00 a.m. and from 3:00 p.m. to 6:00 p.m. when the weather conditions were convenient and birds become active [23].

To minimize disturbance during the census, a waiting period of 3-5 minutes prior to counting individuals of avian species was maintained [24]. During data collection, the observer and assistants stood at a particular point for a fixed time (10 minutes), and all birds that could be seen within a fixed radius of $25 \mathrm{~m}$ were recorded.

Species observed during the survey were identified and taxonomically classified following Sinclari and Ryan [25].
Avian identification was based on different morphological features such as plumage pattern, color, body size, and shape [26]. We additionally used a field guide to the birds of East Africa [27]. Observations were assisted by binoculars, and photographs were also taken for further confirmation of the species.

2.5. Data Analysis. Data analysis methods for this study were performed using the Shannon-Wiener diversity index $\left(\mathrm{H}^{\prime}\right)$, Simpson's Index of Diversity $(D)$, and quantitative and qualitatively by using ANOVA and chi-square. 
The species diversity was calculated using the formula provided by Shannon and Weaver [28] as

$$
H^{\prime}=-\left(\sum_{1}^{96} P i \operatorname{Ln} P i\right),
$$

where $H^{\prime}$ is the Shannon-Wiener index, $P i$ is the proportion of the $i$ th species, and Ln is the Natural Logarithm.

Equitability or evenness index was calculated by using the ratio of observed diversity to the maximum diversity using

$$
E=\frac{H^{\prime}}{H \max },
$$

where $E$ is the evenness index, $H^{\prime}$ is the Shannon-Wiener diversity index, and $H$ max is the natural $\log$ of the total number of species.

Simpson's Index of Diversity $(D)$ was used to evaluate the relative abundance of avian species in each habitat type. It is a measure of diversity that takes into account both richness and evenness. The index gives the probability of any two individuals drawn from a noticeably large community belonging to different species.

$$
D=1-\left(\frac{\sum n(n-1)}{N(N-1)}\right),
$$

where $n$ is the total number of individuals of a particular species, and $N$ is the total number of individuals of all species.

The relative abundance of each species was estimated from encounter rates. This value is used to give each species an ordinal rank of abundance using the ranking scale of Bibby et al. [29]. Encounter rate was calculated for each species by dividing the number of birds recorded by the number of hours spent searching, to get the number of individuals per hour for each species.

$$
\text { Encounter rate }=\frac{\text { number of individual of a species }}{\text { number of observation hours }} \times 100 \text {. }
$$

Following Bibby et al. [21], encounter rate values were used to categorize each species into the following five abundance categories: <0.1, 0.1-2.0, 2.1-10.0, 10.1-40.0, and $>40$. For each category, the following abundance score was given: 1 (Rare), 2 (Uncommon), 3 (Frequent), 4 (Common), and 5 (Abundant), respectively.

Simpson's similarity index (SI) (Simpson, 1949) was used to evaluate the similarity of species between four different habitats in both seasons by using the following formula:

$$
\mathrm{SI}=\frac{4 C}{F}+L S+S+W
$$

where SI is Simpson's similarity index, $F$ is the number of species that occur in forest habitat, $L S$ is the number of species that occur in lakeshore habitat, $S$ is the number of species that occur in shrubland habitat, $W$ is the number of species that occur in wetland habitat, and $C$ is the number of common species that occur in all habitat types.
The Chi-square test was used to compare seasonal variations in diversity and evenness of birds at the $95 \%$ level of significance. ANOVA was used to analyze the effect of season and habitat. SPSS (version 20.0) statistical program was used to run the analysis.

\section{Results}

3.1. Species Composition. In the present study, a total of 96 avian species belonging to 38 families were identified from all study sites during both the wet and dry seasons. Of these, the majority (9 species) of the species are in the family Alcedinidae (Kingfishers), which was followed by Anatidae and Columbidae (7 species for each). Two of the total species identified were endemic to Ethiopia (blue-winged goose (Cyanochen cyanoptera) and yellow-fronted parrot (Poicephalus flavifrons)). Among the total 96 species, 40 species were recorded only during the wet season, while 13 species were recorded only during the dry season and 43 species were recorded during both seasons (Table 2).

3.2. Species Diversity. Variations in species diversity among the different habitats during the wet and dry seasons were recorded. Thus, species diversity was higher during the wet season in all habitats compared to the dry season (Tables 3-5).

During the wet season, the highest diversity of avian species was recorded in the wetland habitat $\left(H^{\prime}=3.3\right)$, followed by forest habitat $\left(H^{\prime}=2.9\right)$, and then shrub habitat $\left(H^{\prime}=2.7\right)$, and the lowest diversity was recorded in the lakeshore $\left(H^{\prime}=2.6\right)$ (Table 3$)$.

During the dry season, the lakeshore habitat $\left(H^{\prime}=2.58\right)$ supported the highest diversity of avian species, which was followed by wetland habitat $\left(H^{\prime}=2.51\right)$. The lowest diversity of birds was recorded in the shrubland habitat $\left(H^{\prime}=2.16\right)$ (Table 4).

The highest evenness $(E=0.87$ and $E=0.84)$ was recorded in the shrub habitat during the wet and dry seasons, respectively, and evenness was the lowest in the shrub habitat $(E=0.68)$ when considering both seasons together (Table 5).

3.3. Species Richness. Variation in the number of species was observed among the four different habitats and between seasons in the same habitat. The species composition of birds between the wet and dry seasons showed significant differences $\left(\chi^{2}=17.2, \mathrm{~d} f=2, p<0.05\right)$.

During the wet season, the highest species richness was recorded in the wetland (44) and the lowest in lakeshore (22). During the dry season, the highest species richness was in lakeshore (22) and the lowest in the shrub (13) (Figure 2).

3.4. Species Similarity. Bird species similarity between different habitats showed variations between seasons (Tables 6-8). During the wet season, more species similarity was recorded between lakeshore and wetland habitats 
TABLE 2: Bird species recorded in the study area during wet, dry, and both season surveys, representing the most common species.

\begin{tabular}{|c|c|c|c|c|c|}
\hline \multirow{2}{*}{ SN } & \multirow{2}{*}{ Bird species } & \multirow{2}{*}{ Family } & \multicolumn{3}{|c|}{ Seasons } \\
\hline & & & Wet & Dry & Both \\
\hline 1. & Abdim's stork (Ciconia abdimii) & Ciconiidae & Yes & - & - \\
\hline 2. & AbyssinianSlaty-flycatcher (Melaenornis chocolatina) & Muscicapidae & Yes & - & - \\
\hline 3. & Abyssinian thrush (Turdus abyssinicus) & Turdidae & - & - & Yes \\
\hline 4. & Abyssinian woodpecker (Dendropicos abyssinicus) & Picidae & - & - & Yes \\
\hline 5. & African sacred ibis (Threskiornis aethiopicus) & Threskiornithidae & - & - & Yes \\
\hline 6. & African black duck (Anas sparsa) & Anatidae & - & - & Yes \\
\hline 7. & African collared-dove (Streptopelia roseogrisea) & Columbidae & Yes & - & - \\
\hline 8. & African comb duck (Sarkidiornis melanotos) & Anatidae & Yes & - & - \\
\hline 9. & African darter (Anhinga rufa) & Anhingidae & - & - & Yes \\
\hline 10. & African fish-eagle (Haliaeetus vocifer) & Accipitridae & - & - & Yes \\
\hline 11. & African jacana (Actophilornis africana) & Jacanidae & - & - & Yes \\
\hline 12. & African paradise-flycatcher (Terpsiphone viridis) & Monarchidae & - & Yes & - \\
\hline 13. & African pied wagtail (Motacilla aguimp) & Motacillidae & Yes & - & - \\
\hline 14. & African pygmy-goose (Nettapus auritus) & Anatidae & - & - & Yes \\
\hline 15. & African pygmy kingfisher (Ispidina picta) & Alcedinidae & Yes & - & - \\
\hline 16. & African woolly-neck (Ciconia microscelis) & Ciconiidae & Yes & - & - \\
\hline 17. & Bare-faced go-away-bird (Corythaixoides personata) & Musophagidae & Yes & - & - \\
\hline 18. & Barred warbler (Sylvia nisoria) & Sylviidae & - & - & Yes \\
\hline 19. & Bearded woodpecker (Dendropicos namaquus) & Picidae & - & Yes & - \\
\hline 20. & Bimaculated lark (Melanocorypha bimaculata) & Alaudidae & Yes & - & - \\
\hline 21. & Black-billed barbet (Lybius guifsobalito) & Lybiidae & - & - & Yes \\
\hline 22 & Black-crowned crane (Balearica pavonina) & Gruidae & Yes & - & - \\
\hline 23. & Black-headed weaver (Ploceus melanocephalus) & Ploceidae & Yes & - & - \\
\hline 24. & Black-billed wood-dove (Turtur abyssinicus) & Columbidae & Yes & - & - \\
\hline 25. & Black-headed lapwing (Vanellus tectus) & Charadriidae & Yes & - & - \\
\hline 26. & Black-winged lovebird (Agapornis taranta)-EE & Psittacidae & - & - & Yes \\
\hline 27. & Blue-breasted bee-eater (Merops variegates) & Meropidae & Yes & - & - \\
\hline 28. & Blue-breasted kingfisher(Halcyon malimbica) & Alcedinidae & - & - & Yes \\
\hline 29. & Blue-headed coucal (Centropus monachus) & Alcedinidae & - & - & Yes \\
\hline 30. & Blue-spotted wood -dove (Turtur afer) & Columbidae & Yes & - & - \\
\hline 31. & Blue-winged goose (Cynochen cyanoptera)-E & Anatidae & - & - & Yes \\
\hline 32. & Bronze sunbird (Nectarinia kilimensis) & Nectariniidae & - & Yes & - \\
\hline 33. & Bruce's green-pigeon (Treron waalia) & Columbidae & - & Yes & - \\
\hline 34. & Cattle egret (Bubulcus ibis) & Ardeidae & - & - & Yes \\
\hline 35. & Chestnut-backed sparrow-lark (Eremopterix leucotis) & Alaudidae & - & - & Yes \\
\hline 36. & Citrine wagtail (Motacilla citreola) & Motacillidae & Yes & - & \\
\hline 37. & Collared sunbird (Anthreptes collaris) & Nectariniidae & - & - & Yes \\
\hline 38. & Common bulbul (Pycnonotus barbatus) & Pycnonotidae & - & Yes & \\
\hline 39. & Common fiscal (Lanius collaris) & Laniidae & Yes & - & - \\
\hline 40. & Common sandpiper (Actitis hypoleucos) & Scolopacidae & - & - & Yes \\
\hline 41. & Common stonechat (Saxicola torquata) & Muscicapidae & - & Yes & - \\
\hline 42. & Coppery tailed coucal (Centropus cupreicaudus) & Cuculidae & Yes & - & - \\
\hline 43. & Dark chanting goshawk (Melierax metabates) & Accipitridae & Yes & - & - \\
\hline 44. & Double-toothed barbet (Lybius bidentatus) & Lybiidae & Yes & - & - \\
\hline 45. & Dusky crested flycatcher (Elminia albiventris) & Stenostiridae & Yes & - & - \\
\hline 46. & Eastern plantain-eater (Crinifer zonurus) & Musophagidae & - & Yes & - \\
\hline 47. & Egyptian goose (Alopochen aegyptiacus) & Anatidae & Yes & - & - \\
\hline 48. & Ethiopian bee-eater (Merops lafresnayii) & Meropidae & - & Yes & - \\
\hline 49. & Giant kingfisher (Megaceryle maximus) & Alcedinidae & - & - & Yes \\
\hline 50. & Glossy ibis (Plegadis falcinellus) & Threskiornithidae & - & - & Yes \\
\hline 51. & Goliath heron (Ardea goliath) & Ardeidae & Yes & - & - \\
\hline 52. & Gray-crowned crane (Balearica regulorum) & Gruidae & Yes & - & - \\
\hline 53. & Great reed-warbler (Acrocephalus arundinaceus) & Acrocephalidae & - & - & Yes \\
\hline 54. & Great-white egret (Egretta alba) & Ardeidae & - & - & Yes \\
\hline 55. & Green sandpiper (Tringa ochropus) & Scolopacidae & Yes & - & - \\
\hline 56. & Gray-headed wood pecker (Dendropicos spodocephalus) & Picidae & Yes & - & - \\
\hline 57. & Grey-backed fiscal (Lanius excubitoroides) & Laniidae & - & Yes & - \\
\hline 58. & Grey-headed kingfisher (Halcyon leucocephala) & Alcedinidae & - & Yes & - \\
\hline 59. & Hadada ibis (Bostrychia hagedash) & Threskiornithidae & - & - & Yes \\
\hline
\end{tabular}


TABle 2: Continued.

\begin{tabular}{|c|c|c|c|c|c|}
\hline \multirow{2}{*}{ SN } & \multirow{2}{*}{ Bird species } & \multirow{2}{*}{ Family } & \multicolumn{3}{|c|}{ Seasons } \\
\hline & & & Wet & Dry & Both \\
\hline 60. & Hammer kop (Scopus umbretta) & Scopidae & Yes & - & - \\
\hline 61. & Hooded vulture (Necrosyrtes monachus) & Accipitridae & - & - & Yes \\
\hline 62. & Isabelline wheatear (Oenanthe isabellina) & Turdidae & - & Yes & - \\
\hline 63. & Isabelline shrike (lanius isabellinus) & Laniidae & - & Yes & - \\
\hline 64. & Jameson's fire finch (Lagonosticta rhodopareia) & Estrildidae & Yes & - & - \\
\hline 65. & Lesser-swamp-warbler (Acrocephalus gracilirostris) & Acrocephalidae & - & - & Yes \\
\hline 66. & Little bee-eater (Merops pusillus) & Meropidae & - & - & Yes \\
\hline 67. & Little spotted woodpecker (campethera cailliautii) & Picidae & - & - & Yes \\
\hline 68. & Little weaver (Ploceus luteolus) & Ploceidae & Yes & - & - \\
\hline 69. & Long-crested eagle (Lophaetus occipitalis) & Accipitridae & - & - & Yes \\
\hline 70. & Malachite kingfisher (Alcedo cristata) & Alcedinidae & - & - & Yes \\
\hline 71. & Marsh sandpiper (Tringa stagnatilis) & Scolopacidae & - & - & Yes \\
\hline 72. & Marsh warbler (Acrocephalus palustris) & Acrocephalidae & Yes & - & - \\
\hline 73. & Namaqua dove (Oena capensis) & Columbidae & - & Yes & - \\
\hline 74. & Pied kingfisher (Ceryle rudis) & Alcedinidae & Yes & - & - \\
\hline 75. & Red -billed fire finch (Lagonosticta senegala) & Estrildidae & Yes & - & - \\
\hline 76. & Red-chested cuckoo (Cuculus solitarius) & Alcedinidae & Yes & - & - \\
\hline 77. & Red-eyed dove (Streptopelia semitorquata) & Columbidae & - & - & Yes \\
\hline 78. & Ruppell's robin-chat (Cossypha semirufa) & Muscicapidae & - & - & Yes \\
\hline 79. & Ruppell's weaver (Ploceus galbula) & Ploceidae & Yes & - & - \\
\hline 80. & Sacred ibis (Threskiornis aethiopicus) & Threskiornithidae & - & - & Yes \\
\hline 81. & Silvery-cheeked hornbill (Ceratogymna brevis) & Bucerotidae & - & - & Yes \\
\hline 82. & Speckled mousebird (Colius striatus) & Coliidae & Yes & - & - \\
\hline 83. & 83. Speckled pigeon (Columba guinea) & Columbidae & - & - & Yes \\
\hline 84. & Spectacled weaver (Ploceus ocularis) & Ploceidae & - & - & Yes \\
\hline 85. & Spur-winged goose (Plectropterus gambensis) & Anatidae & - & - & Yes \\
\hline 86. & Spur-winged lapwing (Vanellus spinosus) & Charadriidae & - & - & Yes \\
\hline 87. & Squacco heron (Ardeola ralloides) & Ardeidae & Yes & - & - \\
\hline 88. & Striped kingfisher (Halcyon chelicuti) & Alcedinidae & - & - & Yes \\
\hline 89. & Tropical boubou (Laniarius aethiopicus) & Malaconotidae & - & - & Yes \\
\hline 90. & Wattled ibis (Bostrychia carunculata)-EE & Threskiornithidae & Yes & - & - \\
\hline 91. & White browed coucal (Centropus superciliosus) & Cuculidae & - & - & Yes \\
\hline 92. & White-faced whistling duck (Dendrocygna viduata) & Anatidae & Yes & - & - \\
\hline 93. & White-winged tern (Chlidonias leucopterus) & Laridae & Yes & - & - \\
\hline 94. & White-fronted black chat (Oenanthe albifrons) & Muscicapidae & Yes & - & - \\
\hline 95. & Yellow-billed stork (Mycteria ibis) & Ciconiidae & - & - & Yes \\
\hline 96. & Yellow-fronted parrot (Poicephalus flavifrons)-E & Psittacidae & - & - & Yes \\
\hline
\end{tabular}

$\mathbf{E}=$ Endemic to only Ethiopia, $\mathbf{E E}=$ Endemic to Ethiopia and Eritrea.

TABle 3: Species diversity of birds during the wet season.

\begin{tabular}{lcccccc}
\hline Habitat & Species richness & Abundance & $H^{\prime}$ & $H \operatorname{Hmax}$ & $H^{\prime} / H \max$ & $D=1-\sum P i^{2}$ \\
\hline Forest & 30 & 318 & 2.9 & 3.4 & 0.85 & 0.926 \\
Lakeshore & 22 & 396 & 2.6 & 3.1 & 0.84 & 0.910 \\
Shrub & 23 & 209 & 2.7 & 3.1 & 0.87 & 0.914 \\
Wetland & 44 & 802 & 3.3 & 3.8 & 0.86 & 0.954 \\
\hline
\end{tabular}

TABLE 4: Species diversity of birds during the dry season.

\begin{tabular}{lcccccc}
\hline Habitat & Species richness & Abundance & $H^{\prime}$ & $H \max$ & $H^{\prime} / H \max$ & $D=1-\sum P i^{2}$ \\
\hline Forest & 20 & 172 & 2.44 & 2.99 & 0.81 & 0.874 \\
Lakeshore & 22 & 333 & 2.58 & 3.09 & 0.83 & 0.904 \\
Shrub & 13 & 46 & 2.16 & 2.56 & 0.84 & 0.86 \\
Wetland & 20 & 386 & 2.51 & 2.99 & 0.84 & 0.903 \\
\hline
\end{tabular}


TABLE 5: Species diversity of birds during both seasons.

\begin{tabular}{lcccccc}
\hline Habitat & Species richness & Abundance & $H^{\prime}$ & $H \max$ & $H^{\prime} / H \max$ & $D=1-\sum P i^{2}$ \\
\hline Forest & 17 & 126 & 2.2 & 2.8 & 0.79 & 0.833 \\
Lakeshore & 15 & 228 & 2.1 & 2.7 & 0.79 & 0.85 \\
Shrub & 9 & 72 & 1.5 & 2.2 & 0.68 & 0.82 \\
Wetland & 19 & 357 & 2.4 & 2.9 & 0.89 \\
\hline
\end{tabular}

Note: $H^{\prime}=$ Shannon-Wiener Index; $H / H^{\prime} \max =$ Evenness; $D=$ Diversity Index; $H^{\prime} \max =\ln (S)$.

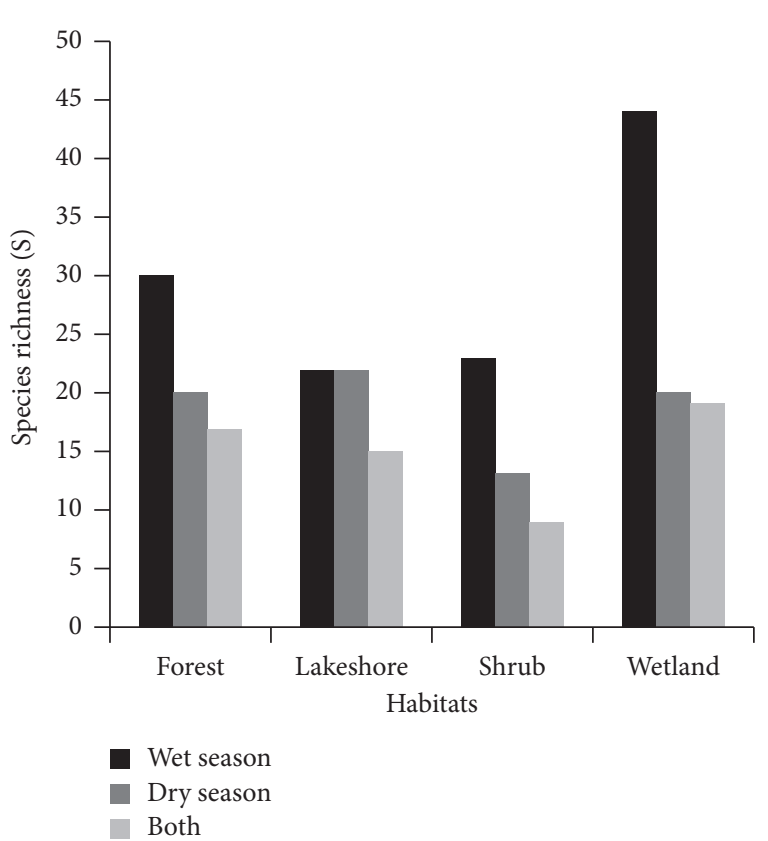

FIgURE 2: Species richness of birds in the four different habitats.

TABle 6: Simpson's similarity index (SI) during the wet season.

\begin{tabular}{lcccc}
\hline Habitat & Forest & Lakeshore & Shrub & Wetland \\
\hline Forest & - & $8(0.31)$ & $10(0.37)$ & $5(0.13)$ \\
Lakeshore & - & - & $6(0.26)$ & $13(0.39)$ \\
Shrub & - & - & - & $3(0.09)$ \\
Wetland & - & - & - & - \\
\hline
\end{tabular}

TABLE 7: Simpson's similarity index (SI) during the dry season.

\begin{tabular}{lcccc}
\hline Habitat & Forest & Lakeshore & Shrub & Wetland \\
\hline Forest & - & $4(0.10)$ & $10(0.60)$ & $2(0.10)$ \\
Lakeshore & - & - & $1(0.06)$ & $6(0.28)$ \\
Shrub & - & - & - & $1(0.06)$ \\
Wetland & - & - & - & - \\
\hline
\end{tabular}

TABLE 8: Simpson's similarity index (SI) during both seasons.

\begin{tabular}{lcccc}
\hline Habitat & Forest & Lakeshore & Shrub & Wetland \\
\hline Forest & - & $3(0.18)$ & $7(0.58)$ & 0 \\
Lakeshore & - & - & 0 & $6(0.35)$ \\
Shrub & - & - & - & $1(0.07)$ \\
Wetland & - & - & - & - \\
\hline
\end{tabular}

Note: Simpson's similarity index $(\mathrm{SI})=2 C / A+B$ where $A$ is the number of species in habitat $A, B$ is the number of species in habitat $B$, and $C$ is the number of common species for both habitats.
$(\mathrm{SI}=0.39) \quad($ Table 6$)$. The least similarity of species was observed between shrub and wetland habitats $(\mathrm{SI}=0.08)$.

During the dry season, the highest similarity was recorded between forest and shrub $(\mathrm{SI}=0.6)$, and the least species similarity was recorded between lakeshore and shrub habitats $(\mathrm{SI}=0.057)$ (Table 7$)$.

Species similarity was higher between bird species of forest and shrubs when considering both the wet and dry seasons together $(\mathrm{SI}=0.58)$ (Table 8$)$. The lowest species similarity was seen between shrub and wetland habitats $(\mathrm{SI}=0.07)$.

Within the same habitat, the percentage comparison of species similarity during the wet and dry seasons showed the highest species similarity in the lakeshore habitat (68.2\%). The least similarity was obtained in the shrub habitat $(50 \%)$ (Table 9).

3.5. Habitat Association. Chi-squared test showed that the distribution of bird species in different habitats was significantly different $\left(\chi^{2}=11.89, \mathrm{~d} f=3, p<0.05\right)$ (Table 10$)$.

Among the observed bird species, 34 (25.2\%) of them were recorded from the forest, $32(23.7 \%)$ of them were recorded from the lakeshore, $29(21.5 \%)$ of them recorded from the shrub, and 40 (29.6\%) of them were recorded from wetland habitats.

Bird species abundance varied among the habitats. During the wet season, the numbers of individuals recorded were 802, 396, 318, and 209 in the wetland, lakeshore, forest, and shrub habitats, respectively. During the dry season, there were $386,333,172$, and 46 individuals in the wetland, lakeshore, forest, and shrub habitats, respectively (Figure 3).

The mean number of individuals per habitat was statistically significant $(p<0.05, \mathrm{~d} f=3)$. This indicates that habitat differences had a significant effect on the abundance of birds. However, there was not a statistically significant difference in the abundance of birds within the same habitat between seasons $(p>0.05, \mathrm{~d} f=2)$.

The relative abundance score and rank of each avian species in different habitats and seasons were determined by using encounter rate data. Encounter rate showed that, during the wet and dry seasons, $32(33.33 \%)$ of the species were frequent and $64(66.67 \%)$ of the species were uncommon.

\section{Discussion}

A total of 96 species of birds were recorded from the study area. Compared to the size of the study area, this result indicates that the area is moderately rich in avian diversity. 
TABle 9: Seasonal species similarity within the same habitats.

\begin{tabular}{lccccc}
\hline Habitats & Wet season & Dry season & Common species & Similarity index (SI) & Species similarity between seasons (\%) \\
\hline Forest & 30 & 20 & 17 & 0.68 & 68 \\
Lakeshore & 22 & 22 & 15 & 0.682 & 68.2 \\
Shrub & 23 & 13 & 9 & 0.5 & 50 \\
Wetland & 44 & 20 & 19 & 0.594 & 59.3 \\
\hline
\end{tabular}

Note: Similarity Index $(\mathrm{SI})=2 C / A+B$

TABLE 10: Multiple pairwise comparisons of mean difference in species abundance in different habitats using LSD.

\begin{tabular}{|c|c|c|c|c|}
\hline (I) habitat & (J) habitat & Mean difference (I-J) & Std. error & Sig. $(p)$ \\
\hline \multirow{3}{*}{ Forest } & Lakeshore & $-7.04^{*}$ & 2.69 & .009 \\
\hline & Shrub & 1.91 & 2.90 & .511 \\
\hline & Wetland & $-9.43^{*}$ & 2.47 & .000 \\
\hline \multirow{3}{*}{ Lakeshore } & Forest & $7.04^{*}$ & 2.69 & .009 \\
\hline & Shrub & $8.95^{*}$ & 2.98 & .003 \\
\hline & Wetland & -2.38 & 2.56 & .353 \\
\hline \multirow{3}{*}{ Shrub } & Forest & -1.91 & 2.9 & .511 \\
\hline & Lakeshore & $-8.95^{*}$ & 2.98 & .003 \\
\hline & Wetland & $-11.34^{*}$ & 2.79 & .000 \\
\hline \multirow{3}{*}{ Wetland } & Forest & $9.43^{*}$ & 2.47 & .000 \\
\hline & Lakeshore & 2.38 & 2.56 & .353 \\
\hline & Shrub & $1.13^{*}$ & 2.79 & .000 \\
\hline
\end{tabular}

${ }^{*}$ The mean difference is significant at the 0.05 level.

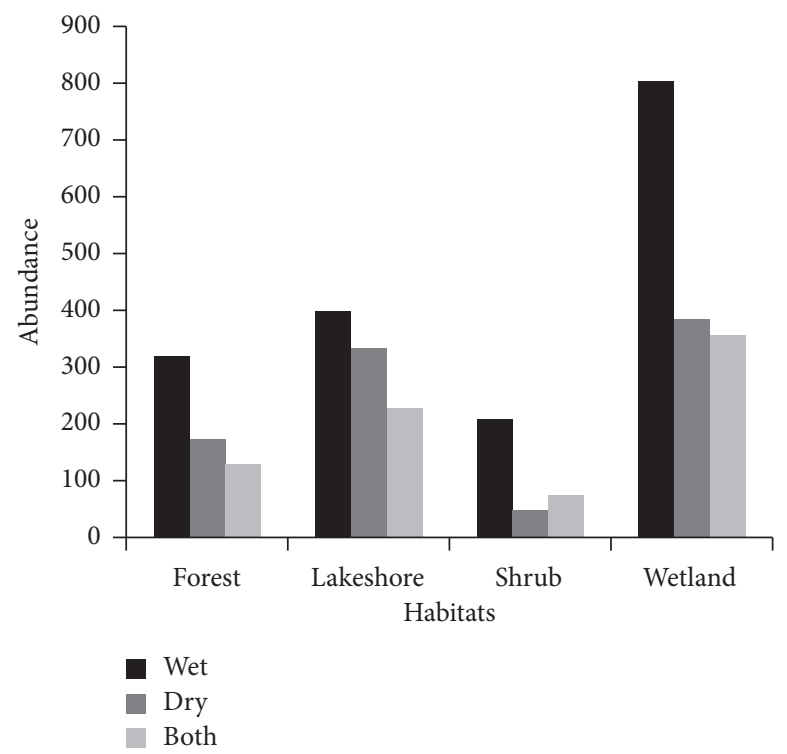

Figure 3: Abundance of the bird during wet, dry, and both seasons from all habitats.

From these recorded avian species, two species, namely, blue-winged goose (Cyanochen cyanoptera) and Yellowfronted parrot (Poicephalus flavifrons), are endemic to only Ethiopia and black-winged lovebird (Agapornis taranta) and Wattled Ibis (Bostrychia carunculata) are endemic to Ethiopia and Eritrea.

A previous study in the same area by Aynalem and Bekele [8] showed that the area harbored 129 bird species. Currently, we have recorded fewer species than Shimelis
Aynalem. This could indicate that diversity is declining because of various anthropogenic activities such as deforestation of trees for timber and cutting trees for firewood. The forest coverage in the area is declining, which could also affect avian diversity [30, 31].

Even though bird species richness and relative abundance are influenced by local resource availability and vegetation composition, a study by Hansson [32] indicated that the number of plant species is not clearly correlated with the 
number of bird species. However, according to Aynalem and Bekele [9], the distribution and abundance of many bird species are determined by the composition of the vegetation that forms a major element of their habitats. Differences in habitat characteristics and feeding habits of bird species in the study area are likely responsible for the variation in species diversity and the number of individuals of bird species among different habitats [33]. Wetlands, forests, lakeshore, and shrubs are the most dominant habitats in our study area.

Wetlands provide a home for a considerable diversity of wildlife including birds, mammals, fish, frogs, and various invertebrate species [34]. This is partly because wetland habitats contain different food sources for these organisms, including water plants and planktons [35]. Wetland birds are heterogeneous in their feeding habits [36]. In the study area, this habitat is enclosed with papyrus vegetation (Cyperus papyrus) and Typha plants. These are important for feeding, nesting, and breeding sites [9]; for instance, black-headed weaver (Ploceus melanocephalus), which was the most dominant bird species in the area, uses papyrus vegetation (Cyperus papyrus) and Typha for nesting. Also, the wetland habitat is close to forest habitat, which could provide an opportunity for lakeshore birds as a waiting area to detect their prey in the nearby Lake Tana.

Most bird species, particularly large tree users like woodpecker species, occur in forest habitats. This is because trees provide nest sites for cavity-nesting birds [37] and they may also support abundant food resources for birds such as arthropods in bark and dead woody tissues [38].

During the dry season, the bird species of the lakeshore habitat were more diverse than other habitats. This might be due to the presence of diversified vegetation cover in the area that provides various functions for different avian species and the availability of food that attracts birds that feed on aquatic animals like fish and crustaceans at the edge of the lake. According to Baker and Baker [39], large numbers of species are expected to occur along the edges of different habitats. Most species of the family Alcedinidae including (African pygmy kingfisher (Ispidina picta), blue-breasted kingfisher (Halcyon malimbica), and giant kingfisher (Megaceryle maximus)) are concentrated in lakeshore habitats as they prey on fish that inhabit the lake. This idea is also supposed by Terborgh et al. [40]. Edge effects may have a great contribution to the increase in the number of species. The lowest avian diversity was recorded in the shrub habitat. This might be because birds move to the adjacent area that has an abundant supply of food and a stable source of food and cover [41].

In addition to this, the low number of species recorded at each habitat type might be due to different reasons including the less conspicuous nature of some avian species and the lower detectability of small cryptic birds in the area [42, 43]. This idea is supported by Tassie and Bekele [44]. Generally, it is difficult to list all species available in a natural community [45].

The study showed that lower avian species diversity was recorded during the wet season in the shrub habitat compared to the other habitat types. This might be because of anthropogenic activities. The local people clear the indigenous trees and they have changed the area to agricultural land for coffee plantation, and this could affect the bird's niche. This finding is in line with Rana [46], who reported that in natural habitats where the intervention of humans is lower, the diversity of species is higher than habitats where intensive farming is apparent.

As the number of vegetation layers increases, the number of available niches for birds also increases and so does the diversity of avian species [47]. The fluctuation of species diversity in different habitats and seasons might be due to the local migration of birds from one habitat to the other in search of food $[48,49]$. Natural seasonal fluctuations and anthropogenic activities are driven in the shrub habitat; as a result, birds migrate to nearby habitats.

During the wet season, the highest species richness was recorded in the wetland, followed by the forest habitat. This might be due to the high availability of resources in the wetlands for wetland birds [50] and the high structural complexity of vegetation in the forest [51]. The difference in species richness between habitats might be due to variations such as topography and vertical and horizontal vegetation structure [52]. The highest evenness value was in shrub habitat, which also had the lowest species richness. This agrees with the idea of Krebs [48], which describes that evenness is independent of species richness.

The analysis of bird species similarity among the four habitat types showed the highest similarity of bird species was observed between the wetland and lakeshore habitats during the wet season and between forest and shrub habitats during the dry season. This similarity might be due to the presence of stable bird niches and the similarity in vegetation composition in the two habitats. This result coincides with the results of Karr [53], which state that faunas under similar ecological conditions are more similar to each other in species richness and topographic structure than faunas under different ecological conditions. In contrast, the least avian species similarity was observed between shrub and wetland habitats $(S I=0.08)$. This might be due to the difference in resources and breeding site requirements among the different bird species.

The distribution of birds within the four habitats varied. This variation might be due to the variation in the foraging strategy of birds. Some groups of birds feed on insects, some on flowers, some on seeds, and others feed on aquatic animals. The distribution and abundance of many bird species are determined by the composition of the vegetation that comprises a major element of their habitats $[52,54]$.

The highest number of individuals was observed in the wetland habitat (40), followed by forest habitat (34). This might be due to the availability of aquatic animals that are used as a food source for birds in wetlands. And also, there is higher vegetation complexity in the forest than in other habitats. As a result, the high number of individual species of birds was concentrated on specific trees. This might be the suitability and the availability of a high amount of fruits. For example, Bruce's Green-Pigeon (Treron waalia) was concentrated on Ficus vasta trees during the dry season.

The difference in the relative abundance of birds recorded at the present study areas might be due to the 
availability of food, habitat condition, and breeding nature of the species. The distinct seasonality of rainfall and seasonal variation in the abundance of food resources result in seasonal changes in the species abundance of birds [52].

It is complicated to estimate the absolute density of species from count data in a multispecies study with dense vegetation. Instead, the encounter rate can be more appropriate. The data provided by the encounter rates do not provide an accurate indication of abundance and are not a substitute for the density estimate. In addition, the relative abundance of species may have little relation with IUCN species category criteria; rather, it is useful to know the abundance of the species in a particular area [8].

The presence of more uncommon species of birds in the present study area might be due to the relatively large home range and large niche requirement of the species. Ryan and Owino [55] suggested that the presence of large numbers of uncommon species in a certain area could be related to the breeding nature and the large home range of the species. In addition, degradation of the habitat might be a reason for the species to be uncommon. Aynalem and Bekele [8] suggested that cutting trees and clearing vegetation for coffee plantations and firewood production to sell to the nearest town were common in the area, and this affects the relative abundance of birds.

\section{Conclusion}

Zegie Peninsula forest patches and associated wetlands support diverse avian species including endemic species of birds in different habitats. During the survey, a total of 96 species of birds belonging to 38 families were identified from the study area. The highest number of bird species were recorded from the family Alcedinidae. Species diversity and richness were higher in both the wetland and forest habitats, and this might be associated with the presence of a sufficient amount of food, habitat conditions, and the breeding nature of species.

There was significant variation in species across habitats. The variation in the habitat depends on the types of vegetation in the area. During the wet season, the diversity of avian species was the highest in wetland habitat and the lowest in shrub habitat. During the dry season, the highest diversity of birds was observed in lakeshore habitats, perhaps because it is an intermediate between aquatic and terrestrial habitats. This habitat plays a great role for opportunistic birds, especially for kingfisher species.

The results of the present study showed that the majority of avian species in the area were known as uncommon and frequent. The forest is shrinking in size from all directions due to various anthropogenic activities including clear cutting of trees for firewood and construction materials (timber production). The wetland habitat is also exposed to overgrazing by livestock which has a negative impact on both birds' diversity and abundance. It seems likely that the bird species diversity in the area will decline.

\section{Data Availability}

The data used and analyzed during the current study are available from the corresponding author upon request.

\section{Conflicts of Interest}

The authors declare no conflicts of interest regarding the publication of this paper.

\section{Authors' Contributions}

$\mathrm{MM}, \mathrm{DE}$, and YY proposed the research idea and collected the data from the respondents. MM organized the data in a computer; did the analysis, interpretation, and identification; and wrote the manuscript. DE and YY revised the manuscript for scientific content and did the language check. All authors read and approved the final manuscript.

\section{Acknowledgments}

The authors are thankful to the local community of Zegie Peninsula for their hospitality and kind response for sharing their accumulative indigenous knowledge with our inquiring data. Moreover, the authors would like to extend their appreciation to the College of Science, Bahir Dar University, which supplied the required materials like GPS and Bird guide book.

\section{References}

[1] Ethiopian Wildlife and Natural History Society (EWNHS), Important Bird Areas of Ethiopia: A First Inventory, p. 300, Ethiopian Wildlife and Natural History Society, Addis Ababa, Ethiopia, 1996.

[2] L. J. Viveropol, A Guide to Endemic Birds of Ethiopia and Eritrea, Shama Books, Addis Ababa, Ethiopia, 2001.

[3] S. Tedla, "Protected areas management crisis in Ethiopia," Walia, vol. 16, pp. 17-30, 1995.

[4] D. W. Yalden and M. J. Largen, "The endemic mammals of Ethiopia," Mammal Review, vol. 22, no. 3-4, pp. 115-150, 1992.

[5] A. Bekele and D. W. Yalden, Mammals of Ethiopia and Eritrea, Addis Ababa University Press, Addis Ababa, Ethiopia, 2013.

[6] WCMC, Endangered Birds, p. 60, World Conservation Monitoring Centre, Chicago, IL, USA, 1995.

[7] J. C. Hillman, Ethiopia: Compendium of Wildlife Conservation Information, Ethiopian Wildlife Conservation Organization, vol. 1, p. 454, Addis Ababa, Ethiopia, 1993.

[8] S. Aynalem and A. Bekele, "Species composition, relative abundance, and habitat association of the bird Fauna of the Montane Forest of Zegie Peninsula and Nearby Islands, Lake Tana, Ethiopia," SINET: Ethiopian Journal of Science, vol. 32, no. 1, 2009.

[9] S. Aynalem and A. Bekele, "Species composition, relative abundance and distribution of bird Fauna of Riverine and Wetland Habitats of Infranz and Yiganda at Southern Tip of Lake Tana, Ethiopia," Tropical Ecology, vol. 49, no. 2, pp. 199-209, 2008. 
[10] A. Shimelis, Birds of Lake Tana Area, Ethiopia, a Photographic Field Guide, View Graphics and Printers, Addis Ababa University Press, Addis Ababa, Ethiopia, 2013.

[11] M. Clouet and J. Joachim, "Variations in bird communities of the Saharan mountains," Ostrich, vol. 84, no. 3, pp. 205-211, 2013.

[12] J. S. Kirby, A. J. Stattersfield, S. H. M. Butchart et al., "Key conservation issues for migratory land- and waterbird species on the world's major flyways," Bird Conservation International, vol. 18, no. S1, pp. S49-S73, 2008.

[13] M. L. Faliarivola, M. J. Raherilalao, A. Andrianarimisa, and S. M. Goodman, "The diet of Malagasy dry forest understory birds based on faecal samples," Ostrich, vol. 91, no. 1, pp. 35-44, 2020.

[14] E. Sande, "Understorey bird species diversity and abundance in three forest types of Semuliki National Park, Uganda," Ostrich, vol. 71, no. 1-2, pp. 64-68, 2000.

[15] Y. Getnet and D. Ejigu, "Community composition, relative abundance and habitat association of avian species in Apini and Dikuma forest patches, Awi Administrative Zone, Ethiopia," Ethiopian Journal of Science and Technology, vol. 10, no. 1, 2017.

[16] D. W. Gibbons, D. A. Hill, and W. J. Sutherland, "Birds," in Ecological Census Techniques: A Handbook, pp. 81-95, Cambridge University Press, New York, NY, USA, 1996.

[17] A. M. Abrah, S. A. Zelelew, H. K. Nigus, and A. Alelign, "Diurnal activity patterns of Harwood's Spurfowl Pternistis Harwoodi in relation to habitat types and climatic conditions in the Central Highlands of Ethiopia," Ostrich, vol. 89, no. 2, pp. 195-201, 2018.

[18] G. Gebeyehu and A. Bekele, "Human-wildlife conflict in Zegie Peninsula (Ethiopia) with emphasis on Grivet Monkey (Cercopithecus aethiops aethiops)," SINET: Ethiopian Journal of Science, vol. 32, no. 2, 2009.

[19] W. J. Sutherland, Ecological Census Techniques: A Hand Book, p. 336, Cambridge University Press, Cambridge, UK, 1996.

[20] C. Bibby and B. Jones, Bird Census Techniques, pp. 239-241, Academic Press, London, UK, 1999.

[21] C. J. Bibby, N. D. Burgess, and H. David, Bird Census Techniques, Academic Press, London, UK, 1992.

[22] A. Rodríguez-ferraro and J. G. Blake, "Diversity patterns of bird assemblages in arid zones of Northern Venezuela," The Condor, vol. 110, no. 3, pp. 405-420, 2008.

[23] G. E. Centerbury, T. E. Martin, D. R. Petit, L. J. Petit, and D. F. Bradford, "Bird communities and habitats are ecological indicators of forest condition in regional monitoring," Conservation Biology, vol. 14, no. 2, pp. 544-558, 2000.

[24] M. E. Hosteler and M. B. Martin, Florida Monitoring Program: Transect and Point Count Method for Surveying Birds, University of Florida, Gainesville, FL, USA, 2001.

[25] I. Sinclari and P. Ryan, Comprehensive Illustrated Filled Guide. Birds of Africa South of the Sahara, p. 759, Struik Publishers, Cape Town, South Africa, 2003.

[26] C. Redman, M. Johnes, and S. Marsden, Expedition Field Techniques: Bird Surveys, pp. 134-137, Royal Geographical Society, London, UK, 2009.

[27] T. Stevenson and J. Fanshawe, A Field Guide to the Birds of East Africa, Bloomsbury Publishing, London, UK, 2001.

[28] C. E. Shannon and W. Weaver, The Mathematical Theory of Communication, University of Illinois press, Urbana, IL, USA, 1949.

[29] C. J. Bibby, M. Jones, and S. Marsden, Expedition Field Techniques: Bird Surveys, pp. 134-137, The Expedition Advisory Center Royal Geographic Society, London, UK, 1998.
[30] D. Pomeroy, Counting Birds. A Guide to Assessing Numbers, Biomass and Diversity of Afro Tropical Birds, p. 25, African Wild Life Foundation, Nairobi, Kenya, 1992.

[31] O. Langrand and L. Wilme, "The effects of forest fragmentation on bird species abundance: a case study of the Central High Plateau of Madagascar," Ostrich, vol. 71, no. 1-2, p. 315, 2000.

[32] L. Hansson, "Environmental determinants of plant and bird diversity in ancient oak-hazel woodland in Sweden," Forest Ecology and Management, vol. 91, no. 2-3, pp. 137-143, 1997.

[33] R. Smith, Elements of Ecology, Harper Collins Publishers Ltd, London, UK, 3rd edition, 1992.

[34] S. Buckton, "Managing wetlands for sustainable livelihoods at Koshi Tappu," Danphe, vol. 16, no. 1, pp. 12-13, 2007.

[35] S. Basavarajappa, "Avifauna of agro-ecosystems of Maidan area of Karnataka," Zoos Print Journal, vol. 21, no. 4, pp. 2217-2219, 2004.

[36] R. B. Colyn, H. A. Campbell, and A. M. Smit-Robinson, "The application of camera trapping to assess Rallidae species richness within palustrine wetland habitat in South Africa," Ostrich, vol. 88, no. 3, pp. 235-245, 2017.

[37] I. Newton, "The role of nest sites in limiting the numbers of hole-nesting birds: a review," Biological Conservation, vol. 70, no. 3, pp. 265-276, 1994.

[38] T. S. Sillett, "Foraging ecology of epiphyte-searching insectivorous birds in Costa Rica," The Condor, vol. 96, no. 4, pp. 863-877, 1994.

[39] M. C. Baker and A. E. M. Baker, "Niche relationships among six species of Shorebirds on their wintering and breeding ranges," Ecological Monographs, vol. 43, no. 2, pp. 193-212, 2002.

[40] J. Terborgh, S. K. Robinson, T. A. Parker III, C. A. Munn, and N. Pierpont, "Structure and Organization of an Amazonian forest bird community," Ecological Monographs, vol. 60, no. 2, pp. 213-238, 1990.

[41] C. Werema, "Seasonal abundance and distribution of redcapped robin chat cossypha natalensis in the eastern arc mountains, Tanzania," Ostrich, vol. 91, no. 2, pp. 129-133, 2020.

[42] B. J. Halstead, J. P. Rose, and P. M. Kleeman, "Time-to-detection occupancy methods: performance and utility for improving efficiency of surveys," Ecological Applications, vol. 31, no. 3, p. 3, 2021.

[43] G. Woldegeorgis and T. Wube, "A survey on mammals of the yayu forest in Southwest Ethiopia," SINET: Ethiopian Journal of Sciences, vol. 35, no. 2, pp. 135-138, 2012.

[44] Nega T. and A. Bekele (2007). The Impact of Habitat Types on the Diversity of Birds in the Dembia Plain Wetland of Lake Tana, Ethiopia.

[45] C. J. Krebs, Ecological Methodologyp. 620, 2nd edition, Addison Welsey Longman, CA, USA, 1999.

[46] S. V. S. Rana, Essentials of Ecology and Environmental Science, Prentice-Hall of India Private Ltd., New Delhi, India, 2nd edition, 2005.

[47] V. R. Cueto and J. L. Casenave, "Determinants of bird species richness: role of climate and vegetation structure at a regional scale," Journal of Biogeography, vol. 26, no. 3, pp. 487-492, 1999.

[48] A. I. Adeyemo and I. A. Ayodele, "Food and feeding ecology of the rock fowl picatthartes oreas in old Oyo National Park, Nigeria," African Journal of Ecology, vol. 43, no. 1, pp. 1-6, 2005. 
[49] T. G. Martin and H. P. Possingham, "Predicting the impact of livestock grazing on birds using foraging height data," Journal of Applied Ecology, vol. 42, no. 2, pp. 400-408, 2005.

[50] R. M. Erwin and R. A. Beck, "Restoration of water bird habitats in Chesapeake Bay: great expectations or Sisyphus revisited?" Water Birds, vol. 30, no. 1, pp. 163-176, 2007.

[51] B. O. Oindo, R. A. De By, and A. K. Skidmore, "Environmental factors influencing bird species diversity in Kenya," African Journal of Ecology, vol. 39, no. 3, pp. 295-302, 2001.

[52] J. R. Karr, "Birds," in Tropical Rain Forest Ecosystems, C. Redman and Johnes, Eds., vol. 24, pp. 401-416, Elsevier, Amsterdam, Netherlands, 1989.

[53] J. R. Karr, "Geographical variation in avifauna's of tropical forest under growth," The Auk, vol. 97, pp. 283-298, 1980.

[54] P.-Y. Lee and J. T. Rotenberry, "Relationships between bird species and tree species assemblages in forested habitats of eastern North America," Journal of Biogeography, vol. 32, no. 7, pp. 1139-1150, 2005.

[55] P. G. Ryan and A. O. Owino, Habitat Association of Papyrus Specialist Birds at Three Papyrus Swamps in Western Kenya, Blackwell Publishing. Ltd, Nairobi, Kenya, 2006. 